\title{
Safeguarding the Kolam Art Form: A Living Culture of Mylapore
}

\author{
Dr. Sharmila Jagadisan* \\ Professor at Aalim Muhammed Salegh Academy of Architecture, Avadi Chennai, India
}

*Corresponding Author: Dr. Sharmila Jagadisan, Professor at Aalim Muhammed Salegh Academy of Architecture, Avadi Chennai, India

\begin{abstract}
Culture is a source of identity and creativity. It is pre-requisite for human development. It is a system of values, norms and behaviors that a society develops over the course of many generations and it has profound influences on the social behavior of people in their everyday lives. A strong cultural identity is fundamental and can make a positive contribution to the health and overall wellbeing of a community. The objective of this article is to demonstrate the importance of culture in community building and to analyze how Kolam, a south Indian art form, enhances community spirit and pride as it creates joyous occasions for socialization, fosters greater harmony and contributes to the development of mutual respect and tolerance. The author has taken Mylapore, Chennai as her case study in analyzing and assessing the role of communities in preserving and retaining its identity and uniqueness of its local culture.
\end{abstract}

Keywords: Mylapore, Safeguarding, Cultural Identity, Behavior, Kolam Art Form

\section{INTRODUCTION}

Culture is an expression of our character or habits in our modes of living and thinking. It is a medium through which the individuals express their innermost thoughts, feelings and their capacity to lead a fulfilling life. Culture is a source of identity and creativity, and it is pre-requisite for human development. It is a system of values, norms and behaviors that a society develops over the course of many generations and it has profound influences on the social behavior of people in their everyday lives. Culture is central to community development and it is a powerful contributor to economic development, social stability and environmental protection (UNESCO, 2012). The purpose of culture is to give humanity a range of permissible behavior patterns in achieving a harmonious society. It is not static but rather a dynamic and constantly evolving ongoing process which gives new perspectives and new experiences. For this reason it is considered as an integral part of a broader developmental process. Cultural identity is imperative for people's self-esteem and how well they relate to others. A strong cultural identity is fundamental and can make a positive contribution to the health and overall wellbeing of a community.

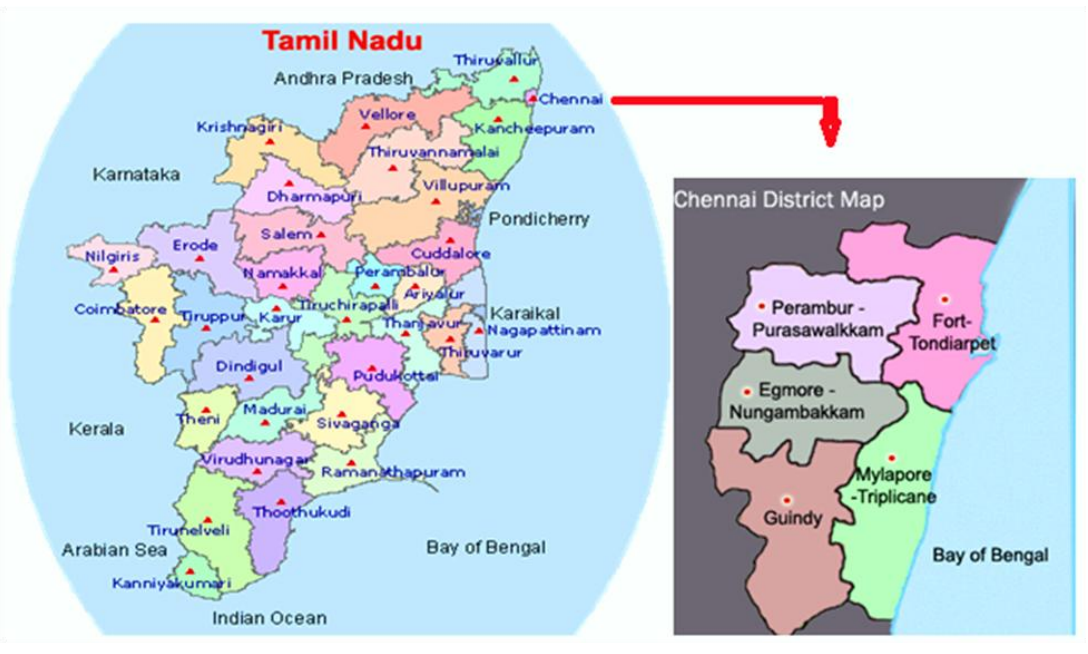

Fig1. Maps of Tamil Nadu and Chennai (Source: Library, MSAJAA) 
The objective of the article is to demonstrate the importance of preserving and safeguarding "Kolam" which is an ephemeral art form of Tamil Nadu in the age of rapid globalization. Since the author is a resident of Mylapore ${ }^{1}$, which is located in Chennai, Tamil Nadu India (refer Fig.1) (for many generations her family members have been living under the same roof) she has chosen that community as a part of her case study to showcase how Mylapore's unique cultural tradition and festivals promotes not only community development but also catalyzes economic and social vitality.

\section{History OF MYLAPORE}

Several centuries before the Europeans arrived; the great $7^{\text {th }}$-century Pallava port was at Mylapore. The splendid Kapaleeswarar Temple, along with the Parthasarathi Temple at Triplicane, bears testimony to the city's great antiquity. Later the Portuguese arrived in $16^{\text {th }}$ century and established a settlement called (São Tomé) Santhome, the sacred site associated with St. Thomas the Apostle. From 1749 Mylapore, fell into the hand of British East India Company.

\subsection{Social Structure}

According to Hancock (2008) Mylapore is often thought of as a Brahman locality, owing to the prominent Brahman writers, lawyers and politicians who have resided there over the past two centuries, and to the iconic signifiers of Brahmanic Hindusim seen on its streetscape temple priests on scooter, the open store fronts of ritual provision shops, older women in traditionally tied saris (Hancock: 2008: p.209). But Mylapore's actual population is far more diverse than its reputation suggests. Scheduled castes make up to 19 percent of the division's population and there are numerous hut colonies and tenements (ibid).

Despite its huge Hindu population, Mylapore community includes other religious affiliations such as Muslims, Jains and Christians. In 1994 an intricately carved Jain temple was constructed here to meet demands of Jain population. Mylapore's proximity to the land formerly granted to the Nawab of Arcot had brought Muslim families to the area, many occupying the commercial and residential streets that adjoin Bazaar road (Hancock:2008: p.210). Here only in Mylapore one can fine seven Shiva temples, seven Vishnu temples, seven Masjids (Mosques) and seven Churches.

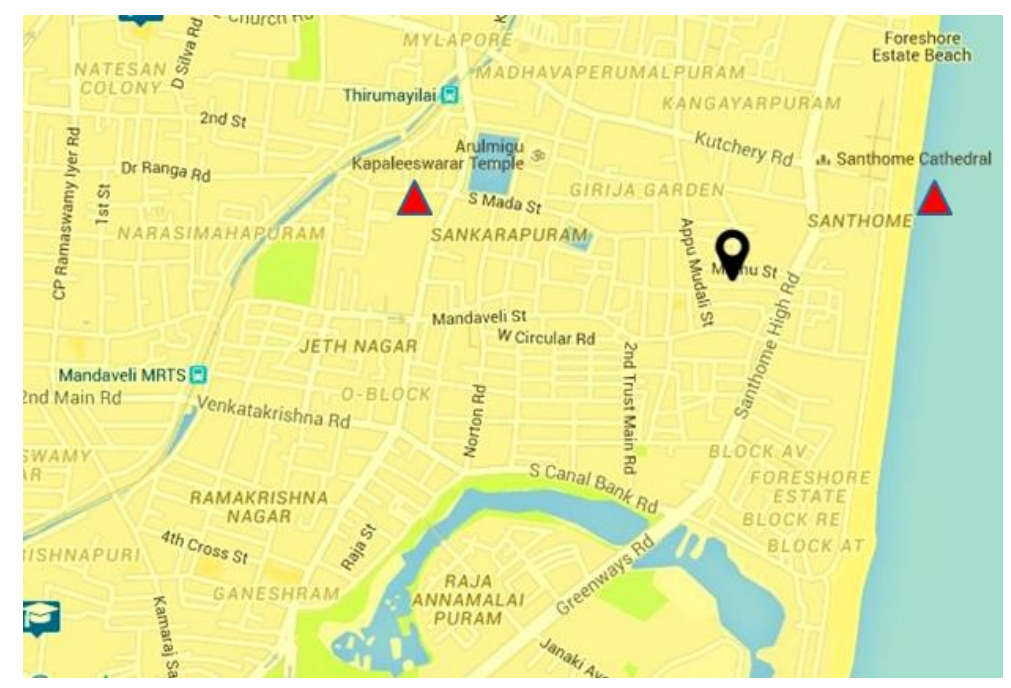

Fig2. shows the important landmarks of Mylapore - Kapaleeshwarar Temple and Santhome Church (Source: Google Map)

Mylapore is a diverse community, made up of many cultural groups with many different customs and traditions. It is a place with varied and vibrant arts and literary culture. This article helps to establish how the Kolam, a south Indian art form, can act as an ally against racial discrimination by providing a sense of identity and belonging to the residents while building strong alliances with diverse communities. The admiration of its history and heritage can help to anchor people's pride since Mylapore's cultural experience through both arts and heritage activity is valuable and unique. As a consequence the number of visitors to this place has been increasing steadily each year and it has been perceived to be one of the key tourist destinations in Chennai.

To substantiate this argument the author would like to give an example of the Kolam festival which is popular during Panguni Thiruvizha ${ }^{2}$ in Kapaleeshwarar temple. 
The grand annual ten day festival of Panguni Utthiram which could be dated back to the $7^{\text {th }}$ century is a supremely auspicious and joyful occasion celebrated with great pomp and glory in different parts of Tamil Nadu (Perur near Coimbatore, Tiru Avinakudi temple at Palani , Sri Kallazhagar Temple, Azahagar Malai to name a few). It is also celebrated in Kuala Lumpur (Malaysia), Singapore and Mauritius.

\subsection{Significance of Panguni Utthiram Festival in Mylapore}

Traditionally Hinduism is extremely rich in festivals and customs which have deep religious and social significance. These festivals follow their own unique rituals usually accompanied by prayers, act of charity and pilgrimage. Being a great source of catharsis these Hindu festivals play a definite role in everyday's life for spiritual and moral enrichment. They teach how to find joy through selfrenunciation and act as a mechanism for emotional integration, affinity for each other and facilitate social bonding promoting unity in diversity.

In Hindu mythology during Panguni Thiruvizha most celestial marriages between deities like Lord Siva and Parvathi, Lord Rama and Sita takes place. It is the celebration that teaches us the significance of relationships in our lives. It is a perceptible indication from the Divine that marriages are sacred union between a man and woman, an initiation into the Grihastha ${ }^{3}$ that is meant to sanctify growth of progeny with the goal of ensuring positive outcomes for future generation.

In Kapaleeshwarar temple (Fig.3) Mylapore, Lord Shiva (alias Kapaleeshwarar) along with Parvati is taken in a procession around the four Mada Veedhi's (four streets around the temple) each day at night.

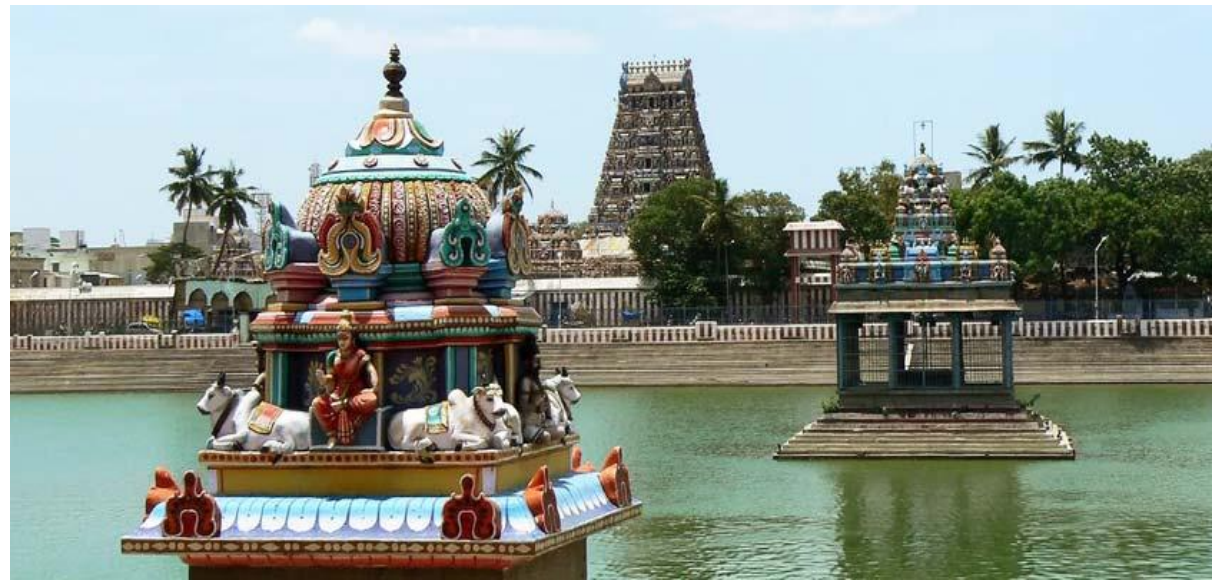

Fig3. Kapaleeshwarar Temple (Source: Isky Techies, Temple website)

Sriram a historian says "No other temple has this big a procession of the 63 Nayanmars (saints) during the eighth day of the Panguni festival Arupattumoovar Vizha (feast of the sixty-three saints) (Refer Fig.4) The unique aspect of the procession is that as the palanquin of Lord Kapaleeswarar (Shiva) moves forward, those of the 63 Nayanmars circumambulate Kapaliswara, moving backwards, facing Lord Shiva with folded hands.

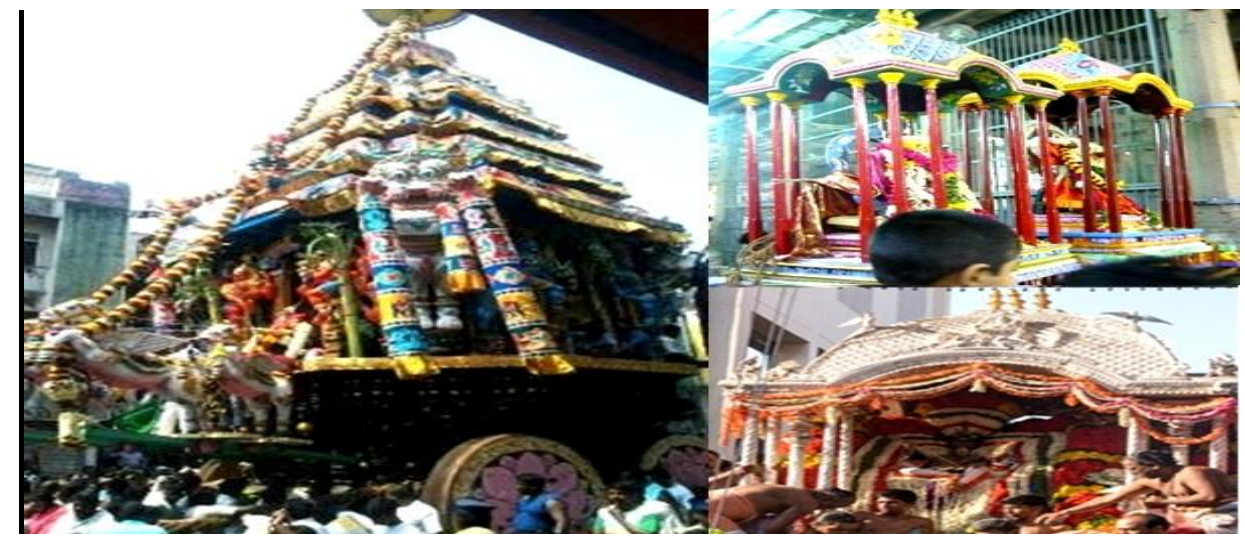

Fig4. shows the Ther (Temple car) on the left and Lord Shiva (Right down) with Nayanmars (Top Right) (Source: Personal Collection, Panguni Thiruvizha, 2016) 
To watch the colorful procession the Mylapore residents in the four Mada streets open their homes to strangers and people climb on the terraces or even take best vantage positions in the first floor. Even the author had a great festival experience this year. During this festival to attract the gaze of the deities Kolams are drawn on the streets approaching the temple. Kolam is an exquisite south Indian art form. It is very crucial that these Kolams are created before sunrise every day especially during the time between four and five in the morning which is called Brahma-muhurtam (the time of God's face when the deities turn their faces towards humans). According to Ayurveda it is an ideal time for meditation and Yoga as one can enter effortlessly into a state of higher consciousness. The Kolam festival is very popular in Mylapore and the intricate design which is drawn with many dots is much more than just an aesthetic art. It is an ornamental floor graffiti painted by Hindu Women of Tamil Nadu which adorns the doorways of the houses, yards, temples, public ceremonial places and the sanctuaries (Fig.5). These kolams are made of a single line and the complex ones with several superimposed figures. The womenfolk who make these kolams are not trained artist and very often not literate but they have extraordinary talents to store these huge repertoire designs and patterns in their memory and retrieve them with ease while drawing.

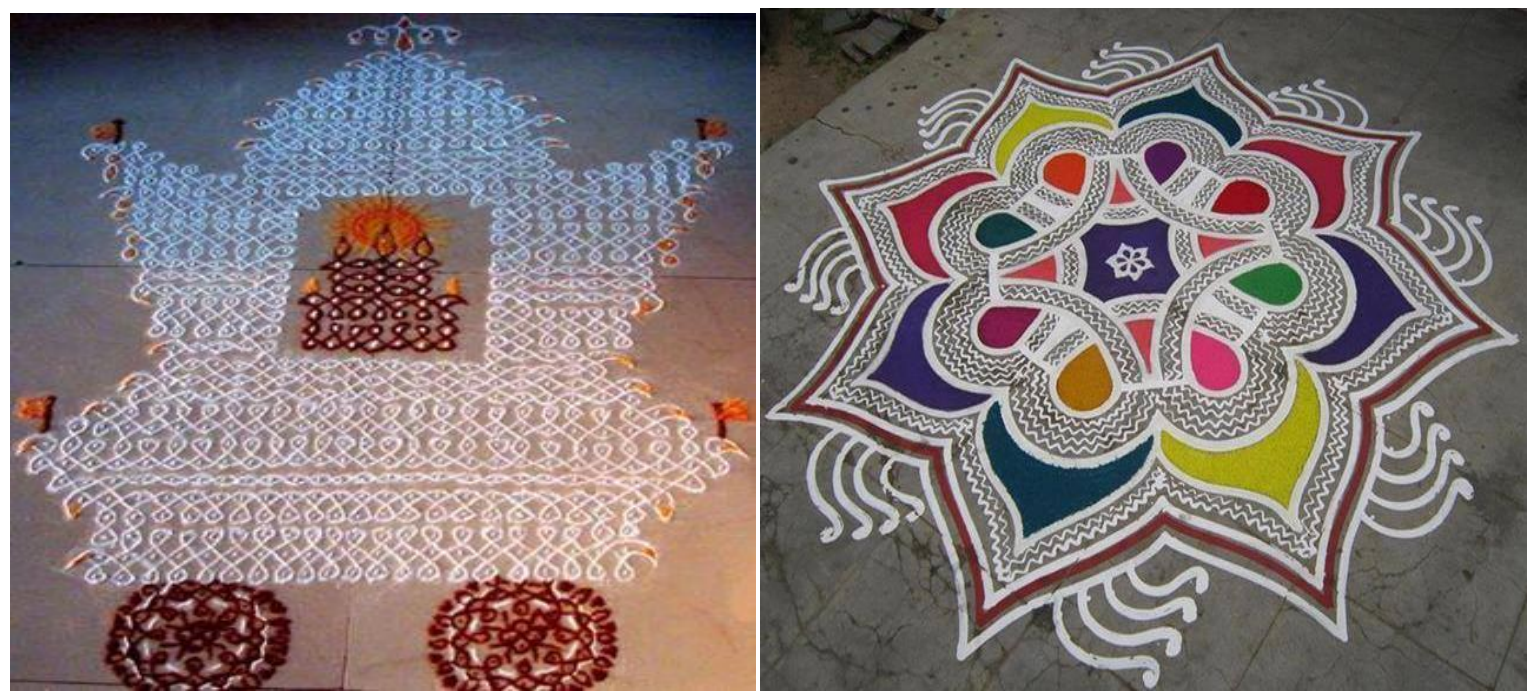

Fig5. Shows the patterns of Kolams (Source: Personal Collection)

\section{History OF KOLAMS}

Floor decoration or Floor Painting is a form of nonverbal folklore of ritualistic folk art and material culture which played a prominent role in many ancient cultures around the world. For example the Native American people like the Pueblo tribe and Navajo tribe created sand paintings which are drawn on the floors to invite friendly spirits in order to heal the person from disease or illness. In Haitian custom Veve or Vévé is a religious symbol drawn on the floor by strewing a powder like substance such as red brick powder, corn or wheat powder.

In Tibetan Buddhist Sand paintings Mandalas were created which is a beautiful sacred art form that was drawn on the floor for healing and meditation purposes. The word mandala itself is a Sanskrit word meaning "circle" and at its deeper levels a mandala represents the wholeness and harmony at the heart of the Tibetan Buddhist universe (Yowangdu, 2012). According to Mulk Raj Anand, "the sources of the folk painting lie in the protection sought by Homo Sapiens in the magical drawing, which may prevent the auras of bad spirits from coming into the house"(1969: p.36). In fact the earliest manifestation of these floor paintings can be traced back to ancient Indus valley civilization which peaked around 2500 B.C. The first visual traces of floor paintings are found in one of the seals of Mohenjo-Daro. Although this ephemeral floor decoration was practiced in many cultures around the world this art form remains in practice in different parts of India even now as a living tradition and it is embedded within the lives of women.

This visual form of floor paintings is known by different names in different geo-cultural pockets of India. For example Kolam in Tamilnadu is known as Rangoli in Maharashtra, Sathiya in Gujarat, , Muggulu in Andhra Pradesh, Rangavali in Karnataka, Chowkpurana in Northern India, Mandana in Rajasthan and Madhya Pradesh, Aripana in Bihar, Alpana in Bengal, Osa or Jhunti in Orissa, Aipan 
in the Himalayan region, Poovidal in Kerala and so on. Kolam in Tamil Nadu plays an integral part especially in the cultural and religious festivals in Tamil Nadu.

If we begin to analyze this ritual with a deeper understanding we would be astonished to know the philosophy behind these decorative arts. Actually these Kolams link the private realm to communal life, hospitality to guests and passersby, the personal and familial to the divine (Menon: No date). These Kolams were drawn with the help of coarse rice flours so as to serve nature's creatures (providing nourishment to ants, insects and rodents) and Lakshmi, goddess of prosperity and wealth. In other words it symbolizes happiness and prosperity. Thus, the Kolam represents man's concern for all living creatures (Suresh: 2003) The Kolam and the bright red border or kaavi enclosing it are also believed to prevent evil and undesirable elements from entering the houses (ibid).

This is supposed to be one of the "Pancha Maha Yagnas" "which form the daily duties of a Hindu \& is called "Bhutha Yagna" which is intended to create in man the spirit of sharing with all living beings (Roy, 2014:p.2). Especially the designs created on the threshold of many Indian houses symbolize the transition between the inner worlds (mind-feelings) to the outer world, which is the physical world of actions. Mastery of kolam art is considered a sign of creativity, grace, dexterity and strong selfdiscipline (ibid) and it requires a great amount of concentration and focus to reach their completion. These intricate designs of Kolams are drawn fresh every morning before sunrise on the threshold of every household in Tamil Nadu. The ephemeral nature of rangoli symbolizes the frailty and the ephemeral aspect of everything in this world because it is created on the beliefs of creation, preservation and destruction. This art work gives our brain a good workout so that when we are overwhelmed with situations it helps us to tackle them smoothly and easily.

Women paint the floors of homes with geometric design and erotic themes connected to goddess worship. The women painters use rice flour for white and vegetable dyes of vivid green, red and yellow for rituals connected to the earth's fertility ( Raman sita: 2009: p.111).

This activity indirectly has an ergonomic impact on the workplace design, their location and body positions (e.g., bending ,squatting etc.). Besides giving aesthetic beauty at the entrance, the kolam also provides a physical exercise for the women, early in the morning (Mahasreerajhan: 2009). The bending and drawing the kolam gives a good exercise to the waist and hips, thereby strengthening them and giving them flexibility (ibid)(Fig.6). This is one example to show how the phenomenon "Kolam" has got a meaning and it should be understood with a deeper understanding.

For example the art of Kolam at the most instrumental level is just a decorative form. But at the latent level it is the activity which improves our creative ability and a very good stress relieving activity.
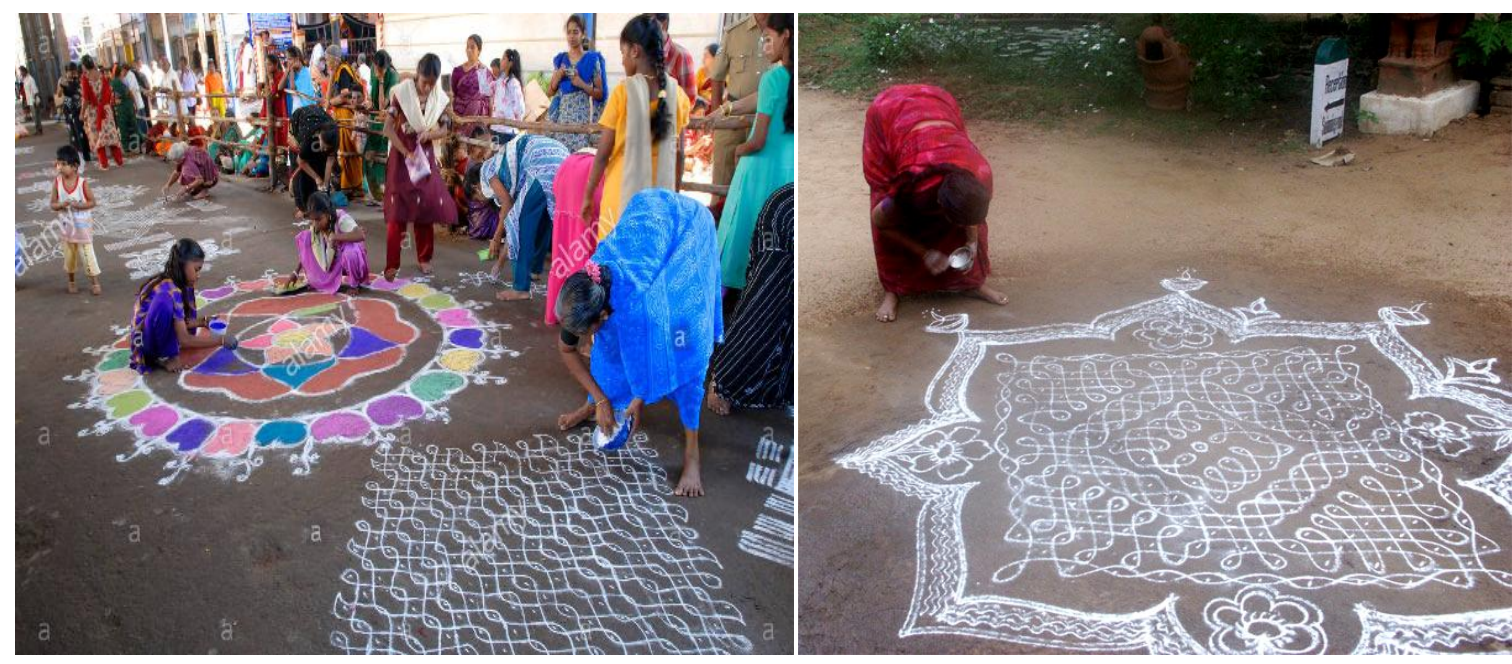

Fig6. shows the art of making kolams ( Source: Personal Collection)

\subsection{How it is Carried Out?}

Normally women folk clean the dirt and dust off the doorstep with a broomstick made of jute, and bend their body in a position which reminds one of an asana, a yoga posture (Smit:2013:p.i). The next step is to clean and pour water on the street. When she puts the Kolam again she brings her body into a position where her upper body is parallel to her legs, her head facing down towards the floor and her 
two feet are far apart, like an inverse V (ibid). From head to foot all the parts are given an exercise and so it is related to yoga.

\subsection{How it is Associated with Other Activities into System?}

The performance of kolam is further organized into a regularity of flows defined by daily, weekly, monthly and annual circumstances related to the rhythm of planets and the following seasons (Laine, 2013). According to a daily rhythm, kolam is also made in front of deities, in temples as well as at altars in homes and at offices (ibid). This art of kolam can be a solitary activity, carried out by servants, a communal activity, a social activity, or a teaching activity for offspring etc. This reveals the importance of the associated activities of kolam art, which varies to a great extent.

\subsection{The Meaning of the Activity}

An intersecting rhythm is defined by the life-cycles of individual household members. During auspicious events, such as a marriage or a temple festival, women draw large and intricate kolams. During inauspicious occasions, such as a death in the family, or the monthly commemoration of ancestors, no kolams are made (ibid). The presence of big kolams indicates the epitome of joy, while their absence means sadness. The way women draw, or refrain from drawing, kolams has an impact on the mood experienced in the community (ibid). Kolam is a sign of social energy or prominence of feminism in the society and it indirectly teaches the society to accept the fact that human life revolves around the presence of women (Roy:2014:pp.8-9)

\section{ROLE OF KOLAM IN MYLAPORE}

Being a resident I always consider Mylapore community as a healthy one because of its ability to preserve and retain its identity and uniqueness of its local culture. Through the history of foreign occupation and into the present times culture has offered an abiding source of identity and stability for the people in Mylapore which is our cultural capital. Following are the reasons to justify why and how these traditional Kolam festivals (refer Fig.7) act as a social mechanism and play a significant and far reaching role in our communities.

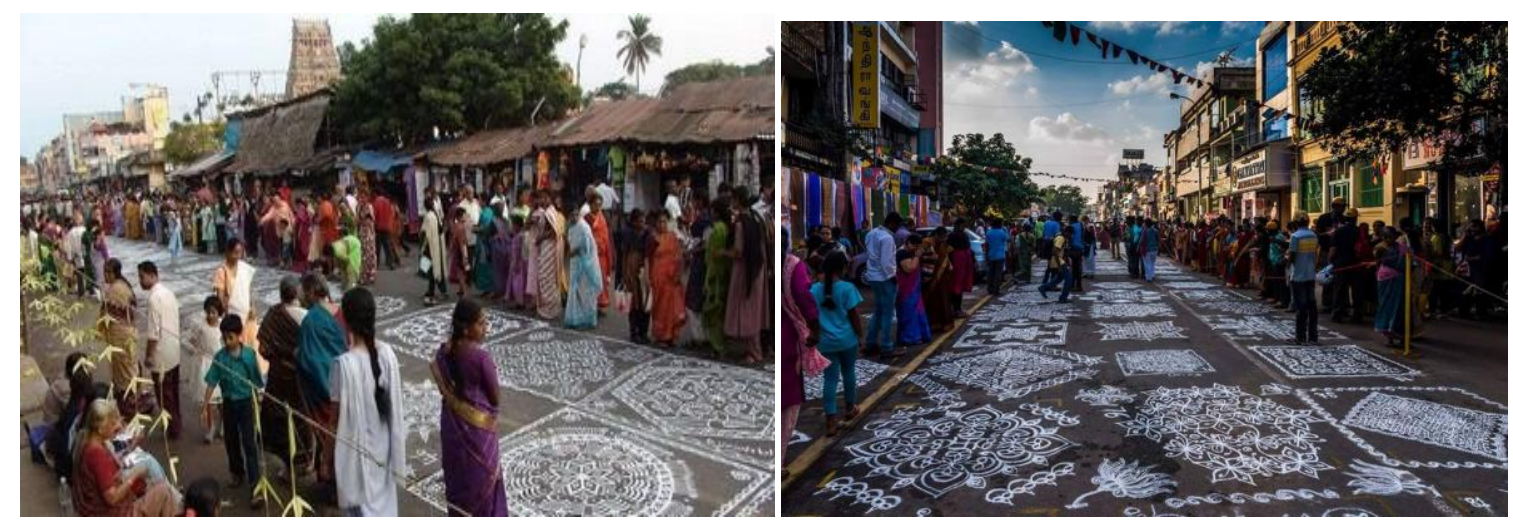

Fig7. shows the kolam competitions held by Sundaram foundation organization to safeguard and protect Mylapore' intangible cultural activities of different kind (Source Mylapore times, 2015)

\subsection{Social Effects of the Kolam Festivals}

The cultural festivals are celebrated to burn our pride, ego and centered upon to promote unity and social harmony. In the so called modern world Mylapore Kolam festival has been sustained through collaborative effort over long periods which have already created community resilience where individuals are treated equal. These festivals are trying to preserve our legitimacy and importance as a positive force for social cohesion by binding families together within the community in lifelong partnership. Every year family reunions have always been popular, especially during this festival which occurs during summer vacation.

\subsection{As an Image Maker}

Festivals are being employed as tools in destination image-making. The emotional attachment to Mylapore and the surrounding built environment, shared memories of communal heritage allow individuals (including author) to come together for formal or spontaneous interactions like festivals and community cultural events. 


\subsection{Festivals Acts as Catalyst for Economic Development}

In most of the Hindu religious complexes outside this holy core one can find tightly knit commercial activities which provide the public with their daily needs. This spectacular Mylapore festival is a ten days long celebration packed with a variety of events ranging from prayers and rituals, artistic performance like Nadaswaram recitals to concerts, folk dances, kolam contest, food and handicrafts stalls etc. It particularly draws people from outside the region (sometimes even foreign visitors prolong their trips to attend this festival) and banking on these crowds small vendors looks forward to this fair. As a result it has direct and indirect impact on our destination development as it revitalizes our local economies.

\subsection{Role of Kolam in Community Building}

Table1. shows the role of Kolam in Community building at the Anthropos/Individual level

\begin{tabular}{|c|c|c|c|c|c|}
\hline & Health Impacts & $\begin{array}{l}\text { Psychological } \\
\text { Impacts }\end{array}$ & $\begin{array}{l}\text { Interpersonal } \\
\text { and } \quad \text { Social } \\
\text { Impacts }\end{array}$ & $\begin{array}{l}\text { Cultural } \\
\text { Impact }\end{array}$ & $\begin{array}{l}\text { Economic and } \\
\text { Environmental } \\
\text { Impacts }\end{array}$ \\
\hline $\begin{array}{c}\text { At The } \\
\text { Individual } \\
\text { / } \\
\text { Anthropos } \\
\text { Level }\end{array}$ & $\begin{array}{l}\text { At the individual/ } \\
\text { Anthropos level, } \\
\text { Kolam art events } \\
\text { encourage active } \\
\text { participation } \\
\text { within } \\
\text { communities, } \\
\text { providing } \\
\text { opportunities } \\
\text { for personal } \\
\text { development. } \\
\text { It is a good } \\
\text { physical and } \\
\text { mental exercise. } \\
\text { This meditative } \\
\text { like state helps the } \\
\text { individual to stay } \\
\text { focus and helps in } \\
\text { great deal of } \\
\text { concentration. } \\
\text { It helps to relieve } \\
\text { stress. Provides } \\
\text { opportunities for } \\
\text { self-expression } \\
\text { and enjoyment. } \\
\text { Increases } \\
\text { propensity } \\
\text { individual of } \\
\text { innovation and } \\
\text { creativity to be } \\
\text { involved in the } \\
\text { arts }\end{array}$ & $\begin{array}{l}\text { Help to improve } \\
\text { self confidence, } \\
\text { flexibility and } \\
\text { self-reliance. } \\
\text { Develops a } \\
\text { capacity for self- } \\
\text { reflection and } \\
\text { evaluation. } \\
\text { Provides a sense } \\
\text { of } \\
\text { accomplishment. } \\
\text { Provides } \\
\text { opportunity in } \\
\text { bringing out } \\
\text { hidden talents } \\
\text { and improves } \\
\text { their cognitive } \\
\text { competencies. It } \\
\text { acts as a therapy } \\
\text { to express their } \\
\text { emotions. }\end{array}$ & $\begin{array}{l}\text { Community } \\
\text { connectedness: } \\
\text { Enhances } \\
\text { ability to work } \\
\text { with others and } \\
\text { communicate } \\
\text { ideas. By } \\
\text { interacting with } \\
\text { their neighbors } \\
\text { builds their } \\
\text { social competence and } \\
\text { provides } \\
\text { foundation for a } \\
\text { stronger } \\
\text { community. }\end{array}$ & $\begin{array}{l}\text { Increase in } \\
\text { Knowledge } \\
\text { and } \\
\text { experience } \\
\text { within this } \\
\text { art } \\
\text { form/domain. } \\
\text { Every } \\
\text { individual } \\
\text { will respect } \\
\text { and own } \\
\text { appreciate } \\
\text { their } \\
\text { culture and } \\
\text { heritage } \\
\text { Increases } \\
\text { sense of } \\
\text { collective } \\
\text { identity and } \\
\text { efficacy. } \\
\text { Greatly } \\
\text { contributes to } \\
\text { the } \\
\text { individual } \\
\text { sense of } \\
\text { belonging. }\end{array}$ & $\begin{array}{l}\text { It provides an } \\
\text { ecological link } \\
\text { with nature as } \\
\text { the ingredients } \\
\text { (rice powder) } \\
\text { used to draw } \\
\text { kolams provide } \\
\text { food source for } \\
\text { ants and insects. } \\
\text { Before adorning } \\
\text { the streets with } \\
\text { Kolams the act } \\
\text { of cleaning up } \\
\text { the front yard } \\
\text { with broom and } \\
\text { water indirectly } \\
\text { improves the } \\
\text { hygienic } \\
\text { conditions of the } \\
\text { surrounding } \\
\text { area. } \\
\text { In many urban } \\
\text { households } \\
\text { Kolams are } \\
\text { drawn with the } \\
\text { help of maid } \\
\text { servants (which } \\
\text { provides income } \\
\text { to those female } \\
\text { workers) }\end{array}$ \\
\hline
\end{tabular}

Table 2 shows the role of Kolam in Community building at the community level

\begin{tabular}{|c|c|c|c|c|c|}
\hline & $\begin{array}{c}\text { Health } \\
\text { Impacts }\end{array}$ & $\begin{array}{l}\text { Psychological } \\
\text { Impacts }\end{array}$ & $\begin{array}{l}\text { Interpersonal } \\
\text { and Social } \\
\text { Impacts }\end{array}$ & $\begin{array}{c}\text { Cultural } \\
\text { Impact }\end{array}$ & $\begin{array}{c}\text { Economic and } \\
\text { Environmental } \\
\text { Impacts }\end{array}$ \\
\hline $\begin{array}{c}\text { At The } \\
\text { Community } \\
\text { Level }\end{array}$ & $\begin{array}{l}\text { Increases } \\
\text { opportunities } \\
\text { for } \\
\text { enjoyment } \\
\text { as it }\end{array}$ & $\begin{array}{l}\text { Increases } \\
\text { tolerance } \\
\text { towards others }\end{array}$ & $\begin{array}{l}\text { Individual and } \\
\text { collective } \\
\text { conscience acts } \\
\text { as mechanism for } \\
\text { community }\end{array}$ & $\begin{array}{l}\text { At the } \\
\text { community } \\
\text { level, these } \\
\text { events bring } \\
\text { citizens from all }\end{array}$ & $\begin{array}{l}\text { Public spaces like } \\
\text { streets provide } \\
\text { opportunities } \\
\text { to be transformed into } \\
\text { creative places. They }\end{array}$ \\
\hline
\end{tabular}




\begin{tabular}{|c|c|c|c|}
\hline $\begin{array}{l}\text { provides } \\
\text { important } \\
\text { leisure } \\
\text { activity } \\
\text { outlets. }\end{array}$ & $\begin{array}{l}\text {, cohesion and } \\
\text { mutual likeness. } \\
\text { It leads to a } \\
\text { greater emotional } \\
\text { well being and a } \\
\text { strong distinctive } \\
\text { identities. } \\
\text { These festivals } \\
\text { captivate, include } \\
\text { and draw people } \\
\text { from all walks of } \\
\text { life who might } \\
\text { not otherwise } \\
\text { come into contact } \\
\text { with each other } \\
\text { and instills a } \\
\text { sense } \\
\text { community } \\
\text {. } \\
\text { It attracts diverse } \\
\text { visitors ranging } \\
\text { from } \\
\text { tourist audience, } \\
\text { local people, past } \\
\text { residents etc }\end{array}$ & $\begin{array}{l}\text { walks of life } \\
\text { so that they } \\
\text { develop a } \\
\text { greater sense of } \\
\text { pride and } \\
\text { ownership } \\
\text { of the place } \\
\text { where they live, } \\
\text { work and play, } \\
\text { which } \\
\text { underpins } \\
\text { engagement } \\
\text { levels and foster } \\
\text { safer } \\
\text { neighbourhoods. } \\
\text { Civic Pride and } \\
\text { community } \\
\text { identity: } \\
\text { Improves } \\
\text { community } \\
\text { image and status } \\
\text { by reminding } \\
\text { our tradition and } \\
\text { ancestors } \\
\text { wisdom } \\
\text { Help } \\
\text { communities to } \\
\text { express their } \\
\text { identity and } \\
\text { their community } \\
\text { character }\end{array}$ & $\begin{array}{l}\text { make it possible to } \\
\text { maximize and } \\
\text { rationalize the use of } \\
\text { certain spaces like } \\
\text { streets and squares. } \\
\text { This duty-bound } \\
\text { activity } \\
\text { will keep our } \\
\text { immediate } \\
\text { surroundings and the } \\
\text { locality neat and clean. } \\
\text { People lesp. } \\
\text { tourists/visitors) spend } \\
\text { money on attending the } \\
\text { arts and on local } \\
\text { businesses. Further, } \\
\text { local and tourist } \\
\text { spending in these arts } \\
\text { venues positively } \\
\text { impacts local } \\
\text { economies and boosts } \\
\text { the quality of life. } \\
\text { Cultural tourism and } \\
\text { Destination marketing: } \\
\text { Showcasing local skills } \\
\text { and local products } \\
\text { promote local } \\
\text { economic sector and } \\
\text { support enterprise }\end{array}$ \\
\hline
\end{tabular}

\subsection{Impact of Modernization on the Traditional Kolam Art Form}

In these modern times of glitter and flashiness, this classical art form of Kolam, despite its richness in culture and tradition, has been performing under par and started losing its distinct identity especially in the urban areas due to shrinking public spaces and fast paced lifestyle. Today Indian women are so deft and self sufficient that they have taken up their careers in corporate sectors and their demands of work and home pose great challenges in practicing this art form in their day to day life. As a consequence Kolam which was once drawn with dry rice flour daily is replaced through modern interpretations like acrylic paints and vinyl stickers for permanency (fig.8). And also there is a marked reduction in the number of women who practice this kolam art on a regular basis and there is no formal transmission to the younger generation.

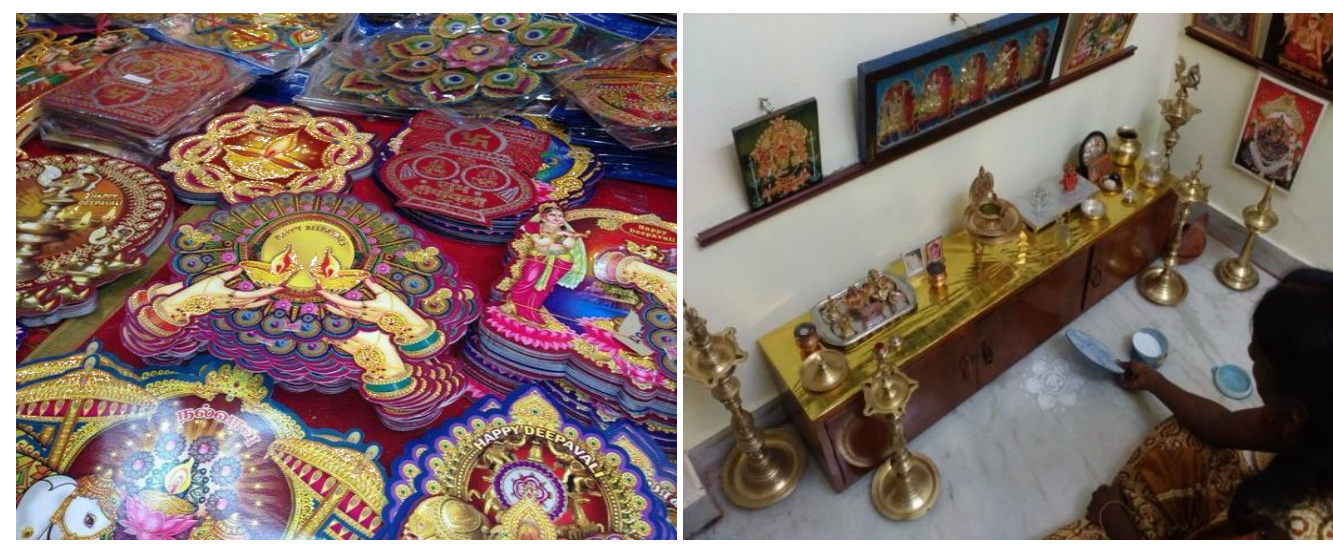

Fig8. Kolam art is getting commercialized in the form of stickers and Kolam instruments

(Source: Personal collection) 


\subsection{Importance in Safeguarding and Promoting the Kolam Art Form}

In order to preserve this art form tradition for posterity and to stimulate interest and appreciation for Kolam it is important to collect relevant information and to archive records of its origin, history and socio-religious practices and innumerable patterns.

Kolam as a domestic art can be incorporated in schools and even in colleges, especially creative industries as elective subjects in order to appreciate the underlying principles of geometry, symmetry and mathematical order, as explained by this tradition. Schools and colleges should encourage students to put up intricate, aesthetically ritual innovative designs of Kolams on the notice board every week.

Since Kolam activity is nested with theoretical framework and inherent--visual, spatial, algebraic and academic concepts it can be incorporated in the Mathematics syllabus so that the students can approach the subjects as an exploration of a new content which will foster the cognitive aspects of the brain.

Special workshops and contests should be organized by the state organizations and cultural institutions to propagate and preserve this ancient and treasured art form. Especially colourful Kolam designs should be drawn mandatorily in all the public sector organizations/offices and in their respective functions.

All Hindu temples should be adorned with Kolams everyday so that it not only provides employment for potential artists but also encourage the youngsters to learn our methods, practice and keep this tradition alive.

Everyday newspapers and magazines should designate one section exclusively to Kolam art to safeguard this women centric art form.

Efforts should be taken to digitize and archive the information about Kolam for the preservation, promotion and dissemination of this art form. This provides an easy means for scholars and interested individuals to access relevant information of their concern and interest.

Recognizing the extreme fragility of this traditional art form Indian Government should proclaim a day to celebrate as "Kolam Day". It not only to raise awareness but will help reinforce the continuity of this beautiful art form to showcase the remarkable contribution of Tamil people' genuine creativity.

Workshops could be organized to teach interested individuals about the technicalities of drawing a Kolam. and we should take pride in preserving this extremely creative art form for the future generations.

\section{CONCLUSION}

Indeed Mylapore is transforming to a heritage zone. Now heritage walks have been promoted every weekend. This experience helps us to find our roots. Revering our past helps in better understanding of our culture and art form by encouraging local pride and fostering social cohesion. Mylapore deserves credit for the way in which so many programs have harmoniously existed while packed in such a small pocket of the city (Rajaraman, 2007:p.20). Cultural participation enhances social cohesion because it creates occasions for socialization that are particularly attractive (ibid). In the current era of globalization many expressions and manifestations of intangible cultural heritage are under threat, endangered by cultural homogenization, and also by a lack of support, appreciation and understanding. If Kolam artform is not nurtured, it risks becoming lost forever, or frozen as a practice belonging to the past. Preserving this Mylapore cultural heritage and passing it on to future generations strengthens it, and keeps it alive while allowing for it to change and adapt (ibid). For the intangible to be stay alive, it must remain relevant to a culture over time and be continuously learned and regularly practiced within communities and between generations.

\section{REFERENCES}

[1] Anand,Raj Mulk. 1969. 'The Hand and the Heart. Notes on the Creative Process in Folk imagination'. Mulk Raj Anand (ed.). Marg Publications. Bombay. Vol.22 [4]. p.36.

[2] Hancock, E. Mary.2008. The Politics of Heritage from Madras to Chennai. Indiana University Press. 
[3] No author (no date), Chennai and Mylapore Map, Library, Mohamed Sathak A.J. Academy of Architecture, Chennai.

[4] Raman, Anatha Sita.2009.Women in India: Social and Cultural History. Vol.1. Praeger/ABC-CLIO.

[5] Rajaraman S. Harini: 2007: Mending the seams of an Urban Patchwork Quilt:Achieving an 'Ordered Chaos' in Temple Towns of Southern India, Thesis submitted for the Bachelor of Science in Art and Design: MIT.

[6] Roy Abhishu.2014.Traditional Knowledge Documentation: Kolam A Visual culture of Southern India. Report submitted by D.J Academy of Design, Coimbatore.pp.1-34

[7] Smit Auke. 2013. The Art of Longing \& Belonging: Kolam as a Reflection of Women's Complex Relations with Identity and Power in Contemporary India. A Master Thesis in Cultural Anthropology. Universiteit Utrecht.

\section{Websites}

[8] Isky Techies. (2016). Arulmighu Kapaleeshwarar Temple, Mylapore, http://www.mylaikapaleeswarar. tnhrce.in/, retrieved on 27th March 2016.

[9] Laine Anna.2013. Kolam patterns as materialisation and embodiment of rhythms in Anthrovision vaneasa online journal: https://anthrovision.revues.org/607: retrieved on 29th November 2014.

[10] No author. 2016.Map of Mylapore. https://www.google.co.in/maps/place/Santhome,+Chennai,+Tamil+ Nadu/. retrieved on 27th March, 2016

[11] Mahasreerajhan.2009.Women's Health and Beauty.http://mahasreerajhan-wwwgoldtime27com. blogspot. in /2009/11 /womens-health-and-beauty.html. retrieved on 29th September 2015.

[12] Menon Madhuri. No date. Design Resource on Rangoli- Kolam Analysis. http://www.dsource.in/resource /rangoli/types-of-rangoli/Kolam/kolam-analysis/index.html, retrieved on 23rd September 2015.

[13] Suresh.S. 2003. Colourful Tradition .http://www.thehindu.com/thehindu/mp/2003/01/07/stories/20030107 00050200.html. retrieved on 24th September, 2015.

[14] UNESCO. 2012. UNESCO Activities for Heritage Safeguarding for Heritage Safeguarding and Cultural Tourism Development: http://dtxtq4w60xqpw.cloudfront.net/sites/all/files/pdf/protection_and_preservatio _of_world_heritage_sites_-_ms._liubava_moreva_0.pdf, retrieved on 8th Aug. 2013.

[15] Yowangdu. 2016. Experience the joys of Tibetan Culture. https://www.yowangdu.com/tibetan-buddhism /sand -mandalas. html. retrieved on 22nd August 2016.

\section{End Notes}

[1] Mylapore popularly called as "Thirumayilai" is located in the southern part of the city of Chennai with a population of 205,000. It is one of the oldest residential neighborhood and has become a major cultural hub and renowned for its religious ceremonies and cultural festivals. Ptolemy, a Greek geographer (140 A.D) in his book has referred Mylapore as Maillarpha. He stated Mylapore to be a well known sea port town with a flourishing trade.

[2] In Tamil language Panguni meaning the Hindu month of March and Thiruziha means festival . It is one of the famous ten day religious festival and it has most awe-inspiring temple processions that occur on the second and eighth days.

[3] Grihastha (Sanskrit: Grhastha) literally means "being in and occupied with home, family".It refers to the second phase of an individual's life in a four age-based stages of the Hindu ashram system.

[4] The Pancha Maha Yagna are: Deva Yagna (worship of Devas (God)), Pitr Yagna (worship of ones forefathers), Manushya Yagna (worship of fellow humans), Bhuta Yagna (worship of other beings), Bramha Yagna (worship of knowledge). Every Family should perform the Pancha Maha Yagna everyday.

\section{AUTHOR'S BIOGRAPHY}

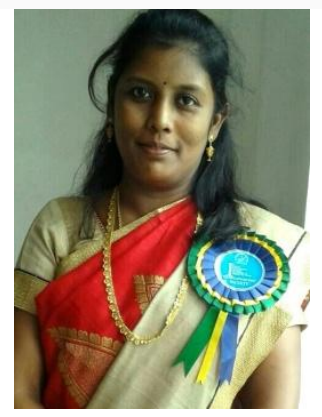

Dr. Sharmila Jagadisan is currently working as a professor at Aalim Muhammed Salegh Academy of Architecture, Avadi, Chennai. She earned her Bachelor degree in Architecture from Madras University and obtained her Masters in City Planning from the Indian Institute of Technology(IIT), Kharagpur. After her post-graduation she received her $\mathrm{PhD}$ in planning from the University of Auckland (UOA), New Zealand. During her PhD she worked as a Tutor and Graduate Teaching Assistant in the planning programme in UOA and assisted with dissemination of findings from a major governmentfunded research project (planning under a Co-operative Mandate). As an 
architect and planner her strong focus has always been to achieve positive outcomes for communities through interdisciplinary thinking. She has been involved in teaching and research since 2001 in the areas of urban planning, housing and community development.

Citation: Dr. Sharmila Jagadisan. "Safeguarding the Kolam Art Form: A Living Culture of Mylapore". International Journal of Humanities Social Sciences and Education (IJHSSE), vol 5, no. 5, 2018, pp. 56-66. doi: http://dx.doi.org/10.20431/2349-0381.0505008.

Copyright: () 2018 Authors. This is an open-access article distributed under the terms of the Creative Commons Attribution License, which permits unrestricted use, distribution, and reproduction in any medium, provided the original author and source are credited. 